\title{
PENGARUH PENGEMBANGAN KARIR TERHADAP KINERJA KARYAWAN PADA KANTOR PUSAT PENELITIAN KELAPA SAWIT UNIT MARIHAT PEMATANGSIANTAR
}

\author{
Oleh: \\ Ayub Budiargo \\ S1 Manajemen \\ Darwin Lie, Marisi Butarbutar, Efendi
}

\begin{abstract}
Abstraksi
Adapun rumusan masalah penelitian ini adalah bagaimana pengaruh pengembangan karir terhadap kinerja karyawan pada Kantor Pusat Penelitian Kelapa Sawit Unit Marihat Pematangsiantar. Dalam metode penelitian, penulis melakukan penelitian kepustakaan dan penelitian lapangan, jenis datanya adalah data kualitatif dan kuantitatif, dengan sumber data adalah data primer dan sekunder. Analisa data yang dilakukan dalam penelitian ini yaitu analisa deskriptif kualitatif dan kuantitatif. Analisa deskriptif kuantitatif terdiri dari regresi linier sederhana, analisis koefisien korelasi, nilai perhitungan determinasi, dan uji hipotesis (Uji t). Adapun sampel yang digunakan dalam penelitian ini adalah sebanyak 145 responden.

Hasil analisa dari regresi linier sederhana yaitu $\hat{Y}=22,93+0,41 \mathrm{X}$ artinya, terdapat pengaruh yang positif antara pengembangan karir terhadap kinerja karyawan. Hasil analisa korelasi yaitu nilai $\mathrm{r}$ sebesar 0,48 yang artinya kekuatan hubungan kedua variabel positif dan sedang. Hasil analisa koefisien determinasi yaitu 23,04\% tinggi rendahnya kinerja dapat dijelaskan oleh pengembangan karir, sedangkan 76,96\% dipengaruhi oleh faktorfaktor lain yang tidak dibahas pada penelitian ini seperti: budaya organisasi, motivasi, kompensasi dan sebagainya. Dari hasil analisa, penulis menyimpulkan bahwa pengembangan karir berpengaruh positif terhadap kinerja karyawan pada Kantor Pusat Penelitian Kelapa Sawit Unit Marihat Pematangsiantar. Hal ini dibuktikan secara matematis melalui uji hipotesis, dimana $t_{\text {hit }}(6,56)>t_{\text {tab }}(1,9764)$. Untuk itu, pelaksanaan sistem promosi dalam pengembangan karir harus dilakukan secara merata dan memberikan kesempatan kepada karyawan mengikuti pelatihan. Sedangkan dalam pelaksanaan kinerja sebaiknya perusahaan memberikan peningkatan kinerja dan pelatihan kepada karyawan berkemampuan serta mengadakan kegiatan olahraga untuk memajukan kerjasama antar karyawan.
\end{abstract}

Kata Kunci: Pengembangan Karir dan Kinerja

\section{Abstraction}

As for this research problem formula is how influence of career development to employees performance at Head Office of Oil Palm Research Unit Marihat Pematangsiantar. In research method, writer do library research and field research, its data type is data qualitative and quantitative, with the data source is data of primary and secunder. Analyse the data of performed within this research that is descriptive analysis qualitative and quantitative. The quantitative descriptive analysis consisted of linear regresi modestly, analyse the correlation coefficient, assess the calculation determinasi, and test the hypothesis (Test the t). As for sampel used in this research as much 145 responder.

Result of analysis from linear regresi modestly that is $\hat{Y}=22,93+0,41 X$ meaning, there are influence which are positive between career development to employees performance. Result of correlation analysis that is assess the requal to 0,48 which its meaning is the strength of relationship between the variables is positive and moderate. Result of analysis of coefficient determinasi that is 23,04\% high and low of performance can explainable by career development, while $76,96 \%$ influenced by other dissimilar factors which is not studied at this research like: organizational culture, motivate, compensation, etc. From result analyse the writer conclude that career development have an effect on positive to employees performance at Head Office of Oil Palm Research Unit Marihat Pematangsiantar. This Matter is proved mathematically by hypothesis test, where $t_{\text {hit }}$ $(6,56)>t_{\text {tab }}(1,9764)$. For that, execution of promotion system in career development must be done flattenedly and give the opportunity to employees follow the training. While in execution of company performance better give the make-up of performance and training to capable employees and also perform the athletic activity to move forward the cooperation usher the employees.

Keyword: Development of Career and Performance

\section{A. PENDAHULUAN}

\section{Latar Belakang Masalah}

Dalam suatu organisasi, kinerja perorangan (individual perfomance) sangat mempengaruhi kinerja organisasi (organization perfomance), baik itu organisasi pemerintahan maupun swasta dalam mencapai tujuan yang telah ditetapkan. Dengan kata lain, tercapainya tujuan organisasi dikarenakan adanya upaya yang dilakukan oleh orang-orang dalam organisasi tersebut. Kinerja pegawai yang 
baik akan berdampak pada kinerja organisasi secara keseluruhan, yang pada akhirnya dapat terlihat dari pencapaian organisasi.

Pusat Penelitian Kelapa Sawit Unit Marihat Pematangsiantar merupakan salah satu perusahaan yang bergerak dibidang Penelitian Kelapa Sawit, meliputi semua aspek dari perakitan bahan tanaman, tekhnik budidaya, hingga pengelolaan hasil dan kajian sosial ekonominya. Selain melakukan penelitian dan pengembangan, Pusat Penelitian Kelapa Sawit Unit Marihat Pematangsiantar juga mempunyai tugas memberikan pelayanan kepada pengguna jasa, peneliti, pelajar, instansi pemerintah dan lain-lain.

Kinerja karyawan Pusat Penelitian Kelapa Sawit Unit Marihat Pematangsiantar bisa dikatakan belum optimal, dikarenakan tingkat kedisiplinan masih belum optimal dalam hal jam masuk kerja, kualitas dan kuantitas pekerjaan yang belum optimal dikarenakan pemanfaatan jam kerja belum efektif, ini disebabkan adanya pegawai yang belum memanfaatkan waktunya dengan sebaik-baiknya. Kemudian tingkat kehadiran pegawai yang cenderung menurun, tingkat kedisiplinan yang kurang diterapkan karena masih adanya karyawan yang tidak hadir tanpa keterangan, yang sakit tanpa adanya pemberitahuan, datang dan pulang tidak tepat waktu jam kerja.

Salah satu upaya Pusat Penelitian Kelapa Sawit Unit Marihat Pematangsiantar dalam meningkatkan kinerja adalah pengembangan karir karyawan yang berupa, penilaian prestasi kerja, pelatihan dan pendidikan yang diberikan kepada karyawan yang memiliki kemampuan, serta kesempatan melanjutkan pendidikan bagi para karyawan yang memiliki prestasi kerja yang baik. Pengembangan karir yang dilaksanakan Pusat Penelitian Kelapa Sawit cukup baik namun belum optimal dikarenakan belum secara merata didapatkan semua karyawan, ini dilihat dari beberapa karyawan dengan masa kerja sudah cukup lama namun belum mendapatkan promosi.

\section{Rumusan Masalah}

a. Bagaimana gambaran pengembangan karir dan kinerja karyawan pada Kantor Pusat Penelitian Kelapa Sawit Unit Marihat Pematangsiantar?

b. Seberapa besar pengaruh pengembangan karir terhadap kinerja karyawan pada Kantor Pusat Penelitian Kelapa Sawit Unit Marihat Pematangsiantar?

\section{Tujuan Penelitian}

a. Untuk mengetahui gambaran pengembangan karir dan kinerja karyawan pada Kantor Pusat Penelitian Kelapa Sawit Unit Marihat Pematangsiantar.

b. Untuk mengetahui besarnya pengaruh pengembangan karir terhadap kinerja karyawan pada Kantor Pusat Penelitian Kelapa Sawit Unit Marihat Pematangsiantar.

\section{Metode Penelitian}

Desain penelitian merupakan suatu cara yang sistematis dan objektif dengan maksud untuk memperoleh data atau mengumpulkan keterangan untuk diteliti. Adapun Desain penelitian yang digunakan dalam penulisan skripsi ini adalah Penelitian Kepustakaan (Library Research) dan Penelitian Lapangan (Field Research).

Teknik pengumpulan data yang dilakukan penulis dalam penelitian ini adalah berupa Kuesioner, Wawancara dan Dokumentasi. Adapun jenis data yang digunakan dalam penelitian ini adalah jenis data kualitatif dan data kuantitatif. Hasil data yang diperoleh dari lapangan akan dianalisis secara deskriptif baik bersifat kualitatif dan kuantitatif.

\section{B. LANDASAN TEORI}

1. Manajemen Sumber Daya Manusia

Menurut Rivai (2004:5), manajemen sumber daya manusia dapat diartikan sebagai pengolahan pendayagunaan sumberdaya yang ada pada individu (karyawan). Sedangkan menurut Daft (2007:6), manajemen adalah pencapaian tujuan organisasi dengan cara yang efektif melalui perencanaan, pengorganisasian, pengarahan, dan pengendalian sumber daya organisasi. Jadi pada dasarnya, manajemen sumber daya manusia adalah suatu proses menangani berbagai masalah pada ruang lingkup karyawan, pegawai, buruh, manajer, dan tenaga kerja lainnya untuk dapat menunjang aktivitas organisasi atau perusahaan demi mencapai tujuan yang telah ditetapkan.

Menurut Dessler (2004:2), manajemen sumber daya manusia mempunyai lima fungsi manajemen, yaitu :

a) Perencanaan, yaitu menentukan sasaran dan standar-standar, membuat aturan dan prosedur, menyusun rencana-rencana dan membuar pemikiran.

b) Pengorganisasian, yaitu memberikan tugas spesifik pada setiap karyawan, membuat divisidivisi, mendelegasikan wewenang kepada bawahan, membuat jalur wewenang dan komunikasi, mengkoordinasikan pekerjaan bawahan.

c) Penyusun staf, yaitu menentukan tipe orang yang harus dipekerjakan, merekrut calon karyawan, memilih karyawan, menetapkan standar prestasi, memberikan konseling kepada karyawan, melatih dan mengembangkan karyawan.

d) Kepemimpinan, yaitu mendorong orang lain menyelesaikan pekerjaan, mempertahankan semangat kerja, memotivasi karyawan.

e) Pengendalian, yaitu menetapakan standar seperti kuota penjualan, standar kualitas atau tingkat produksi, memeriksa atau melihat bagaimana prestasi yang dicapai dibandingkan dengan standar-standar ini, melakukan korelasi jika dibutuhkan. 


\section{Pengembangan Karir}

Menurut Mondy (2010:228), pengembangan karir adalah pendekatan formal yang digunakan perusahaan untuk memastikan bahwa orang-orang dengan kualifikasi dan pengalaman yang tepat, tersedia saat dibutuhkan. Pengembangan karir merupakan rangkaian kegiatan seumur hidup. Pengembangan karir juga proses pelaksanaan (implementasi) perencanaan karir. Selanjutnya menurut Rivai (2004:290), Pengembangan karir adalah proses peningkatan kinerja individu yang dicapai dalam rangka mencapai karir yang diinginkan. Jadi dapat disimpulkan bahwa pengembangan karir adalah suatu tahap ataupun rangkaian kegiatan seseorang dalam mencapai rencana ataupun tujuan karirnya.

Menurut Siagian (2006:215), faktor-faktor yang mempengaruhi perkembangan karir seorang karyawan adalah sebagai berikut:

a) Prestasi kerja yang memuaskan

Pangkal tolak pengembangan karir seseorang adalah prestasi kerjanya melakukan tugas yang dipercayakan kepadanya. Tanpa prestasi kerja yang memuaskan, sulit bagi seorang pekerja untuk diusulkan oleh atasannya agar dipertimbangkan untuk dipromosikan ke pekerjaan atau jabatan yang lebih tinggi di masa depan.

b) Pengenalan oleh pihak lain

Yang dimaksud di sini adalah berbagai pihak yang berwenang memutuskan layak tidaknya seseorang dipromosikan seperti atasan langsung dan pimpinan bagian kepegawaian yang mengetahui kemampuan dan prestasi kerja pegawai.

c) Kesetiaan pada organisasi

Merupakan dedikasi seorang pegawai yang ingin terus berkarya dalam organisasi tempatnya bekerja untuk jangka waktu yang lama.

d) Pembimbing dan sponsor

Pembimbing adalah orang yang memberikan nasehat-nasehat atau saran-saran kepada karyawan dalam upaya mengembangkan karirnya. Sedangkan sponsor adalah seseorang di dalam perusahaan yang dapat menciptakan kesempatan bagi karyawan untuk mengembangkan karirnya.

e) Dukungan para bawahan

Merupakan dukungan yang diberikan para bawahan dalam bentuk mensukseskan tugas manajer yang bersangkutan.

f) Kesempatan untuk bertumbuh

Merupakan kesempatan yang diberikan kepada karyawan untuk meningkatkan kemampuannya, baik melalui pelatihan-pelatihan, kursus, dan juga melanjutkan jenjang pendidikannya.

g) Berhenti atas permintaan dan kemauan sendiri Merupakan keputusan seorang karyawan untuk berhenti bekerja dan beralih ke perusahaan lain yang memberikan kesempatan lebih besar untuk mengembangkan karir.

\section{Kinerja}

Menurut Mathis dan John (2006:113), kinerja para karyawan individual adalah faktor yang mempengaruhi keberhasilan suatu organisasi. Selain karyawan dapat menjadi keunggulan bersaing, mereka juga dapat menjadi liabilitas atau penghambat. Ketika karyawan terus menerus meninggalkan perusahaan dan ketika karyawan bekerja namun tidak efektif, maka sumber daya manusia dalam organisasi dalam keadaan rugi. Kemudian menurut Russell (2002:224), kinerja adalah catatan keluaran yang dihasilkan dari fungsi pegawai tertentu atau kegiatan yang dilakukan selama periode waktu tertentu. Berdasarkan penjelasan di atas maka dapat disimpulkan bahwa kinerja karyawan merupakan suatu kemajuan atau pencapaian hasil kerja dengan kriteria tertentu yang dilakukannya berdasarkan potensi yang dimilikinya dengan penilaian dari orang tertentu.

Penilaian kinerja (Performance appraisal) pada dasarnya merupakan faktor kunci guna mengembangkan suatu organisasi secara efektif dan efisien, karena adanya kebijakan atau program yang lebih baik atas sumber daya manusia yang ada dalam organisasi. Dessler (2007:327), mengemukakan bahwa proses penilaian kinerja terdiri dari tiga tahap, yaitu:

a) Mendefinisikan pekerjaan: Pendefinisian pekerjaan berarti memastikan bahwa atasan dan bawahan setuju dengan kewajiban dan standar pekerjaan bawahan

b) Penilaian kinerja: Penilaian kinerja berarti membandingkan kinerja sesungguhnya dari karyawan dengan standar yang telah ditetapkan.

c) Memberikan umpan balik: Pada proses ini, atasan dan bawahannya mendiskusikan kinerja dan kemajuan bawahan, dan membuat rencana untuk pengembangan apapun yang dibutuhkan.

\section{Pengaruh Pengembangan Karir} Terhadap Kinerja Karyawan

Salah satu tujuan penting dari organisasi adalah memastikan bahwa orang-orang mampu melaksanakan bermacam-macam tugas yang berkaitan dengan kedudukan dan peran mereka untuk mencapai tujuan tersebut organisasi harus peka terhadap kesempatan dan keahlian para karyawannya. Dengan adanya pengembangan karir akan mendorong karyawan dalam meningkatkan kinerjanya dengan kemampuan dan keahlian yang dimilikinya, sehingga karyawan dapat menyelesaikan pekerjaan dengan baik. Pengembangan karir yang baik akan berdampak terhadap kinerjanya.

Rivai (2003:299) mengemukakan bahwa tujuan mendasar dari pengembangan karir adalah untuk membantu karyawan menganalisis kemampuan dan minat dalam penyesuaian antara kebutuhan untuk tumbuh berkembang dengan kebutuhan perusahaan. Pengembangan karir juga merupakan hal yang penting dimana manajemen dapat meningkatkan produktivitas, meningkatkan sikap karyawan terhadap pekerjaan dan membangun 
kepuasan kerja yang lebih tinggi.

\section{PEMBAHASAN}

\section{Analisa}

\section{a. Deskriptif Kualitatif}

Analisa deskriptif dimaksudkan untuk mendapatkan gambaran atau deskripsi mengenai tanggapan dari karyawan mengenai Pengaruh Pengembangan Karir Terhadap Kinerja Karyawan Pada Kantor Pusat Penelitian Kelapa Sawit Unit Marihat Pematangsiantar. Sesudah pengujian data, maka langkah selanjutnya peneliti melakukan pengkajian analisa kualitatif sebagai gambaran fenomena dari variabel penelitian pada saat sekarang ini. Adapun penetapan kriteria nilai rata-rata jawaban dari responden tersebut dimasukan ke dalam kelas-kelas interval dimana penentuan intervalnya memakai rumus sebagai berikut :

Interval Kelas $=\frac{\text { Nilai Tertinggi }- \text { Nilai Terendah }}{\text { Jumbh Kelas }}$

Interval Kelas $=\frac{5-1}{5}$

Interval Kelas $=\frac{4}{5}$

Interval Kelas $=0,8$

Dari rumus diatas diperoleh interval kelas = 0,8 , sehingga berlaku ketentuan kategori dengan hasil sebagai berikut :

Tabel 1

Nilai Interval dan Kategori Jawaban Responden

\begin{tabular}{|c|c|}
\hline Nilai Interval & Kategori \\
\hline $1,00-1,80$ & $\begin{array}{c}\text { Sangat Tidak Baik/Sangat } \\
\text { Rendah }\end{array}$ \\
\hline $1,81-2,60$ & Tidak Baik/Rendah \\
\hline $2,61-3,40$ & Cukup Baik/Cukup Tinggi \\
\hline $3,41-4,20$ & Baik/Tinggi \\
\hline $4,21-5,00$ & Sangat Baik/Sangat Tinggi \\
\hline
\end{tabular}

Sumber : Hasil Pengolahan Data

\section{Pengembangan Karir Pada Kantor Pusat Penelitian Kelapa Sawit Unit Marihat Pematangsiantar \\ Pengembangan karir sangat penting bagi} suatu perusahaan, karena karir merupakan kebutuhan yang terus tumbuh dalam diri seorang individu, sehingga dapat mendorong kemampuan kinerjanya. Pengembangan karir juga merupakan harapan untuk meraih posisi atau jabatan yang lebih tinggi maupun lebih baik dari jabatan atau posisi sebelumnya. Pada Kantor Pusat Penelitian Kelapa Sawit Unit marihat Pematangsiantar, tahapan pengembangan karir sangat diperhatikan, dimana diawali dengan tahap pembentukan, yaitu seorang karyawan pada awal masa kerja diharuskan menjalankan tugas dengan sebaik-baiknya dengan perhatian penuh terhadap tanggung jawab kepada perusahaan. Kemudian tahap lanjutan, dimana pencapaian kinerja yang optimal harus dijalankan demi tercapai tujuan perusahaan. Selanjutnya karyawan harus mempertahankan pencapaiannya. Dan kemudian di akhir yaitu tahap pensiun dimana karyawan Kantor Pusat Penelitian Kelapa Sawit Unit marihat mengakhiri karirnya diperusahaan. Tujuan dilaksanakannya pengembangan karir Kantor Pusat Penelitian Kelapa Sawit Unit marihat Pematangsiantar yaitu untuk mengembangkan kemampuan karyawannya. Memilih karir yang tepat sesuai kemampuan diri. Namun di samping itu seorang karyawan harus memiliki prestasi kerja yang memuaskan, kesetiaan terhadap perusahaan maupun dukungan dari rekan kerja.

Dengan pengembangan akan menguntungkan organisasi dan karyawan. Karyawan dan manajer yang memiliki kemampuan yang terbaik dan sesuai akan meningkatkan daya saing organisasional. Begitu juga dengan karyawan, pengembangan yang diberikan kepada karyawan akan memberikan kemampuan yang baru dan peningkatan yang berbeda yang didapatkan oleh karyawan. Pengembangan karir yang dilakukan oleh kantor Kantor Pusat Penelitian Kelapa Sawit Unit marihat Pematangsiantar untuk meningkatkan kapabilitas maupun kemampuan para karyawan dan manajer.

Pada kuesioner prestasi kerja yang memuaskan poin pertama diperoleh nilai rata-rata 4,23 dan dikategorikan sangat baik sesuai dengan kriteria jawaban yang ditentukan, karena sebagian besar karyawan memiliki keahliannya masingmasing. Pada poin kedua menunjukkan bahwa kepercayaan perusahaan pada hasil kerja karyawannya dikategorikan baik dengan nilai ratarata 4,05 ini karena setiap karyawan selalu menyelesaikan pekerjaan dengan baik dan bertanggungjawab. Pada indikator kedua yaitu pengenalan oleh pihak lain, hasil kuesioner poin pertama yaitu sistem promosi dari atasan diperoleh rata-rata jawaban responden sebanyak 3,90 hal ini dikategorikan baik karena karyawan merasakan apresiasi atas segala kemampuan dan kinerja mereka. Sedangkan pada poin kedua hubungan dengan pihak promosi diperoleh nilai rata-rata sebesar 3,70 juga dikategorikan baik karena adanya hubungan baik karyawan dengan pihak yang melakukan promosi memberikan keuntungan bagi karyawan.

Poin pertama pada indikator kesetiaan pada organisasi dari hasil kuesioner diperoleh rata-rata jawaban responden sebanyak 3,76 dikategorikan baik karena karyawan merasa perusahaan telah memberikan apresiasi berdasarkan dengan tanggungjawab atas tugas yang diberikan. Pada poin kedua diperoleh nilai rata-rata 4,09 dikategorikan baik karena perusahaan memberikan yang terbaik untuk kesetiaan karyawan terhadap perusahaan. Dari hasil jawaban responden pada indikator keempat yaitu kesempatan untuk bertumbuh diperoleh nilai rata-rata poin pertama sebesar 3,86 dikategorikan baik karena perusahaan memberikan kesempatan terhadap karyawan yang telah diberikan pelatihan. Pada poin kedua diperoleh nilai rata-rata 3,92 dikategorikan baik karena setiap karyawan merasa lebih baik karena hubungan dengan pembimbing akan memberikan mereka keuntungan.

Untuk hasil indikator terakhir yaitu berhenti atas permintaan dan kemauan sendiri, diperoleh nilai rata-rata sebesar 3,86 dikategorikan baik karena 
karyawan merasakan bahwa karir yang diberikan perusahaan lebih baik dibanding perusahaan lain. Pada poin kedua nilai rata-rata sebesar 3,87 dinilai baik menurut interval yang ditentukan karena karir yang diberikan di perusahaan akan berdampak baik pada peningkatan kerja karyawan.

Dari semua hasil indikator tersebut dapat disimpulkan bahwa faktor-faktor pengembangan karir dinilai baik dengan nilai rata-rata keseluruhan 3,92 hal ini karena pengembangan karir akan memberikan dampak yang positif terhadap setiap karyawan dalam menjalankan pekerjaannya.

\section{Kinerja Karyawan Kantor Pusat Penelitian Kelapa Sawit Unit Marihat Pematangsiantar}

Kinerja adalah hasil pekerjaan yang dicapai dari suatu pekerjaan yang dilakukan. Untuk mengetahui kinerja seorang karyawan diperlukan penilaian kinerja. Penilaian kinerja pada kantor Pusat Penelitian Kelapa Sawit dilakukan dua kali dalam setahun. Kinerja dinilai oleh Kepala bagian SDM beserta staf SDM kantor Pusat Penelitian Kelapa Sawit yang menilai kinerja karyawannya tiap semester. Kinerja Karyawawan pada kantor Pusat Penelitian Kelapa Sawit Unit marihat Pematangsiantar dinilai dari kemampuannya dalam menjalankan tugas dan tanggung jawab pekerjaannya. Karena setiap karyawan harus menunjukkan kinerja terbaik agar mendapat dukungan baik dari rekan kerja maupun organisasi. Sikap serta kegigihan dalam menyelesaikan pekerjaan merupakan usaha yang akan diberi aperesiasi oleh perusahaan. Kinerja yang maksimal dari karyawan akan diberikan kesempatan untuk di kembangkan karirnya, seperti mendapatkan pendidikan, promosi serta penghargaan dari perusahaan. Kinerja maksimal yang diberikan karyawan akan memberikan dampak positif terhadap perusahaan. Dengan kinerja tinggi yang diberikan karywan akan memberikan kemajuan perusahaan dan akan lebih cepat mencapai target perusahaan.

Pada indikator pertama diperoleh nilai ratarata sebesar 4,37 pada poin pertama dikategorikan sangat tinggi dimana tingkat pencapaian target kerja karyawan slalu sangat baik karena setiap karyawan selalu meningkatkan kinerjanya. Pada poin kedua nilai rata-rata yang diperoleh sebesar 4,14 dan dikategorikan tinggi, karena setiap karyawan menyelesaikan pekerjaan utamanya dengan baik. Pada indikator kedua poin pertama diperoleh nilai rata-rata 3,83 dan dikategorikan tinggi karena setiap karyawan menjalankan tugasnya dan berdasarkan standar perusahaan. Pada poin kedua diperoleh nilai rata-rata sebesar 3,92 dikategorikan tinggi, karena stiap karyawan berusaha melewati standar perusahaan dengan meningkatkan kinerjanya agar semakin tinggi.

Pada indikator ketiga poin pertama diperoleh nilai rata-rata 4,19 dikategorikan tinggi karena setiap karyawan memanfaatkan waktu dengan sebaikbaiknya agar tidak ada waktu yang terbuang sia-sia. Pada poin kedua diperoleh nialai rata-rata 4,04 yang dikategorikan tinggi karena setiap karyawan menyelesaikan pekerjaannya tepat waktu. Pada indikator keempat diperoleh nilai rata-rata sebesar 4,04 pada poin pertama yang dikategorikan tinggi, karena setiap pegawai hadir tepat waktu di kantor. Kemudian pada poin kedua diperoleh nilai rata-rata sebesar 3,70 yang dikategorikan tinggi karena pemberian sanksi akan membuat setiap karyawan selalu datang tepat waktu. Pada indikator kelima poin pertama diperoleh nilai rata-rata sebesar 3,39 yang dikategorikan cukup tinggi dikarenakan masih belum semua karyawan dapat bekerjasama dengan baik. Pada poin kedua diperoleh nilai rata-rata sebesar 3,52 yang dikategorikan tinggi karena setiap karyawan mampu bekerja sama dengan pimpinan dengan baik.

Dari seluruh uraian diatas dapat disimpulkan bahwa kinerja karyawan yang dinilai dari kuantitas, kualitas, ketepatan waktu, kehadiran dan kemampuan bekerjsama dinilai tinggi, dapat dilihat dari total nilai rata-rata keseluruhan yang diperoleh sebesar 3,92. Namun dalam hal kerjasama karyawan belum optimal dikarenakan nilai rata-rata sebesar 3,39 yang dikategorikan cukup tinggi.

\section{b. Deskriptif Kuantitatif \\ 1) Analisa Regresi Linear Sederhana}

Penilaian ini memliki tujuan untuk menganalisa pengaruh pengembangan karir terhadap kinerja karyawan. Analisa data dalam penelitian ini menggunakan analisis regresi sederhana. Analisa regresi linier sederhana digunakan untuk mengetahui pengaruh variabel bebas $(\mathrm{X})$ dan variabel terikat $(\mathrm{Y})$, dimana $\mathrm{X}$ adalah pengembangan karir dan $\mathrm{Y}$ adalah kinerja karyawan.

Analisa dilakukan dengan melakukan tabulasi jawaban responden pada kuesioner yang telah dijalankan. Untuk melihat pengaruh variabel dengan persamaan regresi tersebut, maka dilakukan perhitungan secara manual untuk memperoleh nilai a dan nilai $b$, dengan notasi sebagai berikut :

$$
\hat{\mathrm{Y}}=\mathrm{a}+\mathrm{bX} \text {. }
$$

Untuk nilai $\mathrm{b}$ :

$$
\begin{aligned}
& \mathrm{b}=\frac{\mathrm{n}\left(\sum \mathrm{XY}\right)-\left(\sum \mathrm{X}\right)\left(\sum \mathrm{Y}\right)}{\mathrm{n}\left(\sum \mathrm{X}^{2}\right)-\left(\sum \mathrm{X}\right)^{2}} \\
& \mathrm{~b}=\frac{145(223.008)-(5.690)(5.678)}{145(224.264)-(5.690)^{2}} \\
& \mathrm{~b}=\frac{32.366 .610-32307820}{32.518 .280-32.376 .100} \\
& \mathrm{~b}=\frac{58.790}{142.180} \\
& \mathbf{b}=\mathbf{0 , 4 1}
\end{aligned}
$$

sedangkan untuk nilai a :

$$
\begin{aligned}
& \mathrm{a}=\left(\sum \mathrm{Y}-\mathrm{b} \sum \mathrm{X}\right) / \mathrm{n} \\
& \mathrm{a}=(5.678-0,41(5.690)) / 145 \\
& \mathrm{a}=5.678-2.332,9 / 145 \\
& \mathrm{a}=3345,1 / 145 \\
& \mathbf{a}=\mathbf{2 2 , 9 3}
\end{aligned}
$$

Berdasarkan hasil pengolahan data didapat persamaan regresi linier sederhana sebagai berikut : $\hat{\mathbf{Y}}=\mathbf{2 2 , 9 3}+\mathbf{0 , 4 1 X}$ artinya, terdapat pengaruh yang 
positif antara variabel bebas (pengembangan karir) terhadap variabel terikat (kinerja karyawan) pada Kantor Pusat Penelitian Kelapa Sawit Unit Marihat Pematangsiantar. Dimana pengembangan karir yang baik dapat mempengaruhi kinerja karyawan.

\section{2) Analisa Korelasi dan Determinasi}

Untuk Analisis distribusi frekuensi jawaban responden menurut skor dari variabel $\mathrm{X}$ dan $\mathrm{Y}$ dimaksud sebagaimana yang telah dilakukan hanya bermanfaat untuk memberikan informasi pendahuluan mengenai pola distribusi jawaban responden menurut skor. Selanjutnya dilakukan perhitungan korelasi berupa derajat atau kedalaman hubungan fungsional yang menjelaskan hubungan antar perubah, dinyatakan dengan yang dinamakan koefisien yang sering disimbolkan dengan $r$. Nilai $r$ dapat dihitung sabagai berikut :

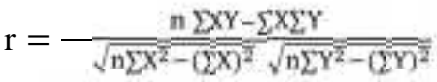

$$
\begin{aligned}
& =\frac{145(223.008)-(5.690)(5.678)}{\sqrt{145(224.264)-(5.690)^{2}} \sqrt{145(223.068)-(5.678)^{2}}} \\
& r=\frac{32.366 .610-32307820}{\sqrt{32.518 .280-32.376 .100} \sqrt{32.344 .860-32.239 .684}} \\
& \mathrm{r}=\frac{58.790}{\sqrt{142.180} \sqrt{105.176}} \\
& r=\frac{58.790}{(377,06)(324,31)} \\
& \mathrm{r}=\frac{58.790}{122.284,32} \\
& \mathbf{r}=\mathbf{0 , 4 8}
\end{aligned}
$$

Dari hasil perhitungan diatas, terdapat hubungan yang sedang dan positif antara variabel $\mathrm{X}$ yaitu pengembangan karir terhadap variabel $\mathrm{Y}$ yaitu kinerja karyawan ini. Hubungan antara variabel $\mathrm{X}$ yaitu pengembangan karir terhadap variabel $Y$ yaitu kinerja karyawan dikatakan sedang karena ada faktor lain yang yang mempengaruhi kinerja karyawan tidak dijelaskan dalam penelitian ini.

Untuk mengukur seberapa besar variabel bebas menjelaskan variabel terikat maka digunakan koefisien determinasi (KD). Nilai KD dapat diperoleh dari :

$$
\begin{aligned}
& \mathrm{KD}=\left(\mathrm{r}^{2}\right) \times 100 \% \\
& \mathrm{KD}=(0,48)^{2} \times 100 \% \\
& \mathrm{KD}=0,2304 \times 100 \% \\
& \mathrm{KD}=\mathbf{2 3 , 0 4 \%}
\end{aligned}
$$

Dari perhitungan koefisien determinasi di atas menunjukkan bahwa tinggi rendahnya kinerja karyawan dapat dijelaskan oleh pengembangan karir sebesar 23,04\%, sedangkan sisanya 76,96\% dipengaruhi oleh budaya organisasi, motivasi, kompensasi dan sebagainya yang tidak dibahas dalam penelitian ini.

\section{3) Uji Hipotesis}

Uji $\mathrm{t}$ digunakan untuk menguji pengaruh variabel bebas terhadap variabel terikat secara parsial atau individual. Untuk menguji hasil perhitungan regresi dapat dilakukan pembuktian hipotesa untuk mengetahui apakah variabel bebas mempunyai pengaruh atau tidak terhadap variabel terikat secara parsial.

$$
\begin{aligned}
& t_{\text {hit }}=\frac{r \sqrt{\mathrm{n}-2}}{\sqrt{1-\mathrm{r}^{2}}} \\
& t_{\text {hit }}=\frac{0,48 \sqrt{145}-2}{\sqrt{1-0,48^{2}}} \\
& t_{\text {hit }}=\frac{0,48 \sqrt{143}}{\sqrt{1-0,2304}} \\
& t_{\text {hit }}=\frac{0,48(11,95)}{\sqrt{0,7696}} \\
& t_{\text {hit }}=\frac{5,74}{0,877} \\
& \mathbf{t}_{\text {hit }}=\mathbf{6 , 5 6}
\end{aligned}
$$$$
\text { Maka dapat dihitung } \mathrm{t}_{\text {hit }} \text { sebagai berikut : }
$$

Selanjutnya dihitung $\mathrm{t}_{\mathrm{tab}}$ berdasarkan rumus interpolasi yaitu:

$$
\begin{aligned}
\frac{143-140}{150-140} & =\frac{x}{1,977-1,975} \\
\frac{3}{10} & =\frac{x}{0,002} \\
x & =\frac{0,006}{10} \\
x & =0,0006 \\
t_{\text {tab }} & =1,977-0,0006 \\
t_{\text {tab }} & =1,9764
\end{aligned}
$$

Dari hasil pengujian $t_{\text {hit }}$ sebesar 6,56 sedangkan $t_{\text {tab }}$ pada tingkat kepercayaan $95 \%$ adalah sebesar 1,9764. Oleh karena $t_{\text {hit }}>t_{\text {tab }}$, berarti pengembangan karir berpengaruh positif terhadap kinerja karyawan, sehingga Ho ditolak dan $\mathrm{Ha}$ diterima, artinya pengembangan karir berpengaruh positif terhadap kinerja karyawan pada Kantor Pusat Penelitian Kelapa Sawit Unit Marihat Pematangsiantar.

\section{Evaluasi}

\section{a. Pengembangan Karir pada Kantor Pusat Penelitian Kelapa Sawit Unit Marihat Pematangsiantar}

Dalam pelaksanaannya beberapa hal yang menjadi faktor mengapa karyawan tidak dapat mengembangkan karirnya mengembangkan karirnya. Bukan hanya dari individu karyawan itu sendiri melainkan juga dengan adanya dukungan dari perusahaan baik atasa maupun rekan teman sekerja yang mendukung. Begitu juga dengan yang dilakukan oleh Kantor Pusat Penelitian Kelapa Sawit Unit Marihat Pematangsiantar yang dalam pelaksanaanya memberikan kegiatan ataupun penilaian dalam upaya untuk mengembangkan karir, baik itu pelatihan maupun kesempatan melanjut pendidikan serta promosi jabatan. Namun tidak semua karyawan dapat menjalaninya dikarenakan syarat maupun ketentuan.

Dalam penerapannya secara keseluruhan nilai rata-rata jawaban responden dari tiap indikator 
sudah berada diatas nilai rata-rata keseluruhan. Namun masih ada beberapa jawaban responden masih berada dibawah total nilai rata-rata. Kekurangan dalam pelaksanaan pengembangan karir, ini bisa dilihat dari indikator pengenalan oleh pihak lain dimana pada poin pertama, sistem promosi dari atasan nilai rata-rata yang diperoleh sebesar 3,90 dan poin kedua yaitu hubungan dengan pihak promosi nilai rata-rata sebesar 3,70. Untuk mengatasinya pihak perusahaan sebaiknya melakukan promosi secara merata dengan melihat karyawan yang setia yang telah lama bekerja dengan prestasi kerja yang baik serta para atasan juga sebaiknya lebih dekat dengan bawahan agar terjalin hubungan yang baik. Kemudian kendala dan kekurangan juga terjadi pada indikator kesetiaan pada organisasi dengan nilai rata-rata 3,76 untuk kategori dampak kesetiaan pada organisasi terhadap karir. Untuk mngatasinya sebaiknya perusahaan memberikan apresiasi terhadap karyawannya yang setia dengan memberikan penghargaan agar karyawan lebih termotivasi.

Kendala juga dialami pada indikator kesempatan untuk bertumbuh pada pada kategori kesempatan yang diberikan perusahaan kepada karyawannya dalam meningkatkan kemampuannya melalui pelatihan dengan nilai rata-rata 3,86 . Untuk mengatasinya sebaiknya perusahaan memberikan kesempatan karyawan yang memiliki kemampuan untuk mejalani pelatihan agar dapat meningkatkan kinerjanya. Pada kategori berhenti atas kemauan sendiri juga terdapat kendala, ini dilihat dari poin pertama yaitu peluang karir dibanding dengan perusahaan lain diperoleh nilai dengan rata-rata 3,86 dan pada poin kedua kesempatan karir yang diberikan perusahaan dengan nilai rata-rata dan 3,87. Untuk mengatasi hal ini perusahaan sebaiknya memberikan kesempatan berkarir yang tepat sesuai dengan kemampuan karyawannya serta memberikan peluang karir yang baik di masa mendatang.

\section{b. Kinerja pada Kantor Pusat Penelitian Kelapa Sawit Unit Marihat Pematangsiantar.}

Kantor Pusat Penelitian Kelapa Sawit Unit Marihat Pematangsiantar mencapai tujuan organisasi salah satunya melalui kinerja para karyawan. Kinerja pegawai juga sudah baik walau karyawan belum memberikan kinerja yang sangat tinggi yang berdasarkan indikator kinerja yaitu kuantitas, kualitas, ketepatan waktu, kehadiran, dan kemampuan bekerjasama yang digunakan untuk mengukur bagaimana pelaksanaan kinerja di Kantor Pusat Penelitian Kelapa Sawit Unit Marihat Pematangsiantar maka dapat dijelaskan sebagai berikut. Pada indikator kuantitas hasil jawaban masing-masing mendapatkan kriteria jawaban yang tinggi. Hal ini dikarenakan setiap karyawan selalu berusaha memberikan kinerja yang terbaik bagi perusahaan.

Pelaksanaan kinerja di kantor Pusat Penelitian Kelapa Sawit Unit Marihat Pematangsiantar berdasarkan nilai rata-rata jawaban responden secara keseluruhan berada pada kategori tinggi yaitu 3,92. Namun masih terdapat beberapa kategori yang berada dibawah nilai rata-rata keseluruhan. Dari segi kualitas mutu pekerjaan yang diselesaikan dibading karyawan lain memiliki nilai rata-rata 3,83. Untuk itu perusahaan harus lebih memotivasi karyawan agar meningkatkan kualitas kerjanya baik dengan memberikan pendidikan dan pelatihan ataupun kegiatan lainnya.

Kemudian dari segi kehadiran juga terdapat kekurangan ini dapat dilihat dari nilai rata-rata 3,70 pada kategori pemberian sanksi apabila terlambat hadir. Untuk mengatasinya sebaiknya perusahaan memberikan sanksi tegas terhadap karyawan yang terlambat agar karyawan lebih tepat waktu hadir di kantor. Selanjutnya dari indikator kemampuan kerja pada kategori kemampuan kerjasama dengan rekan kerja memiliki nilai rata-rata sebesar 3,39 dikategorikan cukup tinggi dan kemampuan kerjasama dengan pimpinan sebesar 3,52 dikategorikan tinggi. Untuk mengatasi hal ini sebaiknya perusahaan mengadakan kegiatankegiatan olahraga ataupun kegiatan yang besifat kerjasama.

\section{KESIMPULAN DAN SARAN} 1. Kesimpulan

a. Dari hasil pengolahan kuesioner tentang pengembangan karir memiliki nilai rata-rata keseluruhan 3,92 dan dikategorikan baik. Namun masih terdapat kekurangan pada karyawan kantor Pusat Penelitian Kelapa Sawit Unit Marihat Pematangsiantar pada beberapa indikator dengan nilai rata-rata berada dibawah nilai rata-rata keseluruhan dalam hal pengenalan oleh pihak lain, kesetiaan pada organisasi, kesempatan untuk bertumbuh dan berhenti atas permintaan dan kemauan sendiri.

b. Dari hasil pengolahan kuesioner tentang kinerja karyawan memiliki nilai rata-rata keseluruhan 3,92 dan dikategorikan tinggi. Namun masih ada kelemahan pada beberapa indikator dengan nilai rata-rata berada dibawah nilai rata-rata keseluruhan yaitu dalam hal kualitas, kehadiran dan kemampuan bekerja sama.

c. Hasil pengujian regresi pengembangan karir terhadap kinerja karyawan, dapat dilihat dalam persamaan regresi $\hat{Y}=22,93+0,41 X$. Hal ini menunjukkan bahwa terdapat pengaruh yang positif antara pengembangan karir (X) terhadap kinerja karyawan (Y) pada Kantor Pusat Penelitian Kelapa Sawit Unit Marihat Pematangsiantar.

d. Melalui analisa koefisien korelasi diketahui bahwa terdapat hubungan yang sedang dan positif antara pengembangan karir terhadap kinerja sebesar 0,48. Hal ini menunjukkan bahwa semakin baik pelaksanaan pengembangan karir yang dilakukan maka semakin baik pula kinerja yang dihasilkan karyawan pada Kantor Pusat Penelitian Kelapa Sawit Unit Marihat Pematangsiantar. Sedangkan koefisien determinasi yang didapat sebesar $23,04 \%$, tinggi 
rendahnya kinerja dapat dijelaskan oleh pengembangan karir dan sisanya $76,96 \%$ dijelaskan oleh faktor-faktor lain yang tidak dibahas dalam penelitian ini.

e. Melalui perhitungan uji $t$ dengan taraf signifikansi $5 \%$ disimpulkan bahwa nilai $t_{\text {hit }}$ $(6,56)>t_{\text {tab }}(1,9764)$ sehingga $\mathrm{H}_{0}$ ditolak. Hasil tersebut menunjukkan bahwa pengembangan karir berpengaruh positif terhadap kinerja karyawan yang dilaksanakan pada Kantor Pusat Penelitian Kelapa Sawit Unit Marihat Pematangsiantar.

\section{Saran}

a. Agar pelaksanaan pengembangan karir dengan indikator prestasi kerja yang memuaskan, pengenalan oleh pihak lain, kesetiaan pada organisasi, kesempatan untuk bertumbuh dan berhenti atas permintaan dan kemauan sendiri haruslah lebih dimaksimalkan pelaksanaan pengembangan karir. Pada indikator pengenalan oleh pihak lain, pihak perusahaan sebaiknya melakukan promosi secara merata dengan melihat karyawan yang setia yang telah lama bekerja dengan prestasi kerja yang baik serta para atasan juga sebaiknya lebih dekat dengan bawahan agar terjalin hubungan yang baik. Selanjutnya pada indikator kesetiaan kepada organisasi, sebaiknya perusahaan memberikan apresiasi terhadap karyawannya yang setia dengan memberikan penghargaan agar karyawan lebih termotivasi.

b. Kinerja harus lebih ditingkatkan demi mencapai tujuan organisasi. Agar semua dapat tercapai Kantor Pusat Penelitian Kelapa Sawit Unit Marihat Pematangsiantar sebaiknya perusahaan harus lebih memotivasi karyawan agar meningkatkan kualitas kerjanya baik dengan memberikan pendidikan dan pelatihan ataupun kegiatan lainnya.

c. Sehubungan dengan keterbatasan-keterbatasan yang ada pada penulis, penelitian ini masih terdapat kelemahan-kelemahan dan belum dapat mengungkap seluruh variabel yang dapat mempengaruhi kinerja karyawan pada kantor Pusat Penelitian Kelapa Sawit Unit Marihat Pematangsiantar. Sebagai bahan masukan untuk penelitian selanjutnya, perlu memperbanyak variabel penelitian, seperti motivasi, kepemimpinan, lingkungan kerja, dan komunikasi.

\section{E. DAFTAR PUSTAKA}

Daft, Richard L, 2007, Management-Manajemen, Edisi keenam, Edisi 1, Jakarta : Salemba Empat.

Dessler, Gary, 2004, Manajemen Sumber Daya Manusia, Jakarta : Prenhallindo. , 2007, Manajemen Sumber Daya Manusia Edisi kesepuluh Jilid 1, Jakarta : PT. Indeks.

Mathis, Robert L, dan John H. Jackson, 2006, Manajemen Sumber Daya Manusia, Edisi Sepuluh, Jakarta : Penerbit Salemba Empat.

Mondy, R. Wayne, 2010, Manajemen Sumber Daya Manusia, Jakarta : Penerbit Erlangga.

Rivai, Veithzal, 2003, Manajemen Sumber Daya Manusia Untuk Perusahaan, Bandung : PT. Remaja Rosda Karya. 2004, Manajemen Sumber Daya Manusia Untuk Perusahaan, Jakarta : Grafindo.

Russel, Bernadin, 2002, Sistem Manajemen Kinerja, Yogyakarta : Penerbit PT. Gramedia Pustaka.

Siagian, Sondang, P., 2006, Manajemen Sumber Daya Manusia, Jakarta : PT Bumi Aksara, 